\title{
PENERAPAN MODEL INKUIRI DALAM MENINGKATKAN HASIL BELAJAR PESERTA DIDIK
}

\author{
Imwarnita \\ SDN 18/IX Rengas Bandung \\ Email: warnitaim@gmail.com
}

\begin{abstract}
This study aims to improve the learning outcomes of science subjects about the relationship between special characteristics possessed by animals and plants using the inquiry model in grade VI at elementary school number 18 / IX Rengas Bandung. The method used in this research is action research with type of classroom action research consists of two cycles and with two meetings of each cycles, the time of this study is semester 1 of the 2019/2020 school year, with subjects in class VI consisting of 13 men and 13 women. Data collection techniques using observation and formative test results were analyzed by comparing the average score. The success criteria are individual KKM at 65, and classical at $80 \%$, The results showed that pre-cycle learning completeness by $15 \%$ increased to $62 \%$ in cycle I and increased again to $92 \%$ in cycle II. teacher activity by $65 \%$ in cycle I increased to $80 \%$ in cycle II, student activity by $60 \%$ in cycle I increased to $78 \%$ in cycle II, Thus, it was concluded that the application of the inquiry model could improve the learning outcomes of science in terms of the relationship between the special characteristics possessed by animals and plants in grade VI students in Elementary School number 18 / IX Rengas Bandung.
\end{abstract}

Keywords: natural science learning, inquiry model, learning outcomes.

\begin{abstract}
Abstrak
Penelitian ini bertujuan untuk meningkatkan hasil belajar peserta didik pelajaran IPA materi hubungan antara ciri-ciri khusus yang dimiliki hewan dan tumbuhan menggunakan model inkuiri pada kelas VI SDN 18/IX Rengas Bandung. Metode yang digunakan Penelitian Tindakan Kelas terdiri dari dua siklus masing-masing siklus dilakukan dua kali pertemuan. Subjek penelitian yaitu kelas VI terdiri dari 13 laki-laki dan 13 perempuan, Teknik pengumpulan data menggunakan observasi dan tes formatif yang dianalisis dengan membandingkan rata-rata skor. Kriteria keberhasilan yaitu KKM individu sebesar 65, dan klasikal sebesar $80 \%$. Hasil penelitian menunjukkan bahwa ketuntasan belajar pra siklus $15 \%$ meningkat menjadi $62 \%$ pada siklus I dan Kembali meningkat menjadi $92 \%$ pada siklus II. Aktivitas guru siklus I $65 \%$ meningkat menjadi $80 \%$, aktivitas peserta didik siklus I $60 \%$ meningkat menjadi $78 \%$ pada siklus II. Dengan demikian disimpulkan bahwa penerapan model inkuiri dapat meningkatkan hasil belajar IPA materi hubungan antara ciri-ciri khusus yang dimiliki hewan dan tumbuhan pada peserta didik kelas VI SDN 18/IX Rengas Bandung.
\end{abstract}

Kata Kunci: pembelajaran IPA, model inkuiri, hasil belajar. 


\section{PENDAHULUAN}

Kemampuan peserta didik dalam menjelaskan dengan kritis, logis, berani dan percaya diri merupakan kompetensi yang harus dicapai peserta didik tingkat SD/MI pada pelajaran Ilmu Pengetahuan Alam (IPA) penerapan kurikulum KTSP sebagaimana termaktub pada Badan Standar Nasional Pendidikan (BSNP) 2006 menyatakan bahwa proses pembelajaran IPA SD/MI menekankan pengalaman langsung peserta didik dalam mengembangkan kompetensi yang tidak hanya berkaitan dengan fakta-fakta, konsepkonsep, atau prinsip-prinsip tentang alam secara sistematis namun juga memiliki kemampuan mengeksplorasi proses penemuan, tentang alam pada prospek lebih lanjut penerapan dalam kehidupan sehari hari.

Namun proses dan hasil pembelajaran tidak selamanya sesuai harapan, begitupula yang terjadi di SDN 18/IX Rengas Bandung, yang saat ini mulai menerapkan K13 kecuali kelas III dan VI, peneliti sendiri diamanahkan menjadi wali kelas VI yang masih menerapkan kurikulum KTSP 2006, penelitian ini berawal dari kesenjangan yang terjadi di kelas peneliti sendiri, dimana ketika proses pembelajaran berlangsung tanpak secara umum sikap apatis peserta didik terhadap pelajaran ipa materi hubungan antara ciri-ciri khusus yang dimiliki hewan dan tumbuhan, sikap yang ditampilkan peserta didik terlihat betul-betul patuh dan penurut, namun setelah peneliti sadari sikap tersebut tidak lebih dari keinginan membahagiakan guru dan bukan merasa butuh untuk mempelajari, mamahami dan mendalami materi pelajaran IPA.

Seringkali peneliti sebagai guru kelas merasa bingung dengan sikap unik peserta didik khususnya pelajaran ipa materi hubungan antara ciri-ciri khusus yang dimiliki hewan dan tumbuhan, Ketika peneliti mengajukan beberapa pertanyaan seperti yang peneliti lakukan pada pelajaran lainnya, sikap peserta didik justru sangat dingin dan sulit untuk peneliti fahami apakah peserta didik sudah mengerti atau justru sebaliknya. Keadaan tersebut mengundang rasa penasaran peneliti 
untuk mencari tau apa yang dialami peserta didik dan bagaimana cara mengatasinya,

Setelah peneliti melakukan wawancara bersama beberapa peserta didik terungkap hal-hal berikut: peserta didik merasa materi hubungan antara ciri-ciri khusus yang dimiliki hewan dan tumbuhan adalah materi yang sulit untuk difahami, peserta didik lebih memilih bersikap baik dengan guru daripada mengikuti pelajaran materi hubungan antara ciriciri khusus yang dimiliki hewan dan tumbuhan, peserta didik mengakui bahwa materi hubungan antara ciriciri khusus yang dimiliki hewan dan tumbuhan membuat peserta didik mudah mengantuk, peserta didik mengakui bahwa materi hubungan antara ciri-ciri khusus yang dimiliki hewan dan tumbuhan membosankan.

Setelah peneliti mengetahui bagaimana persepsi peserta didik satu sisi peneliti merasa sedih karena baru peneliti sadari ternyata pembelajaran yang peneliti terapkan belum maksimal disisi lain fenomena tersebut menjadi umpan balik positif bagi peneliti untuk memperbaiki diri dalam upaya membenahi kesenjangan yang terjadi sekaligus membina profesi sebagai pendidik yang professional, hasil wawancara tersebut semakin jelas ketika peneliti mengetahui hasil belajar peserta didik masih banyak yang belum mencapai KKM, untuk pelajaran IPA kelas VI sendiri sekolah menetapkan KKM sebesar 65 secara individu dan $80 \%$ tuntas secara klasikal, sedangkan hasil ulangan harian peserta didik menunjukkan dari 26 peserta didik hanya empat peserta didik yang tuntas sedangkan 22 peserta didik lainnya belum dinyatakan tuntas, dengan kata lain hanya $15 \%$ yang tuntas sedangkan selebihnya $85 \%$ belum tuntas, dengan rata-rata sebesar 57,69 yang berada pada interval kategori Kurang.

Setelah peneliti mengetahui hasil belajar peserta didik tersebut peneliti langsung merapat kepada teman sejawat dan guru senior, untuk mendengarkan dan mendapatkan pengalaman langsung saat mengajar di kelas, setelah lanjut menempuh kajian pustakaan mencari langkah yang tepat untuk diterapkan pada peserta didik dengan memerhatikan karakteristik pelajaran IPA dan sifat 


\section{Jurnal Sinektik}

Volume 3 Nomor 1, Edisi Juni 2020

Prodi PGSD Universitas Slamet Riyadi

ISSN 2620-6560 (print) ISSN 2620-746X (online)

bahan ajar serta karakteristik peserta didik akhirnya peneliti menemukan dan mempunyai dugaan yang kuat bahwa model inkuiri adalah model pembelajaran yang sangat cocok dengan karakteristik peserta didik dan orientasi pelajaran ipa yaitu mengembangkan kompetensi menjelajahi dan memahami alam sekitar secara ilmiah dengan mendapatkan pengalaman langsung.

Sejalan dengan itu Chiaritto, (Sujana, A., \& Sopandi, P,W, 2017: 64) menyatakan model pembelajaran inkuiri lebih tepat diaplikasikan pada pelajaran ipa atau sains mengingat kesesuaian karakteristik model dan pelajaran. Lebih lanjut Trianto, (2007: 135) menyatakan model inkuiri berorientasi pada pembelajaran merumuskan dan menemukan dengan percaya diri dalam kerangka memaksimalkan kemampuan peserta didik mencari dan menyelidiki. Peran guru dalam penerapan model inkuiri lebih sebagai fasilitator sebagaimana Chiaritto, (Sujana, A., \& Sopandi, $\mathrm{P}, \mathrm{W}$, 2017: 67) mengungkapkan bahwa pada penerapan model inkuiri peran guru sendiri lebih sebagai fasilitator dengan menyediakan berbagai alat dan kebutuhan yang diperlukan untuk melakukan penyelidikan. Sedangkan dalam pelaksanaannya (Sanjaya, 2010: 306) menyatakan 6 (enam) langkah yang ditempuh dalam penerapan model pembelajaran inkuiri yaitu: Orientasi; merumuskan masalah, merumuskan hipotesis, mengumpulkan data menguji hipotesis, dan merumuskan kesimpulan.

Beberapa penelitian muhtahir yang relevan diantaranya Jamalia (2017) dengan fokus meningkatkan hasil belajar peserta didik bidang studi Bahasa Indonesia hasil penelitian menunjukkan bahwa model inkuiri dapat meningkatkan hasil belajar peserta didik dengan hasil ketuntasan belajar sebelumnya $27 \%$ pra siklus meningkat menjadi $75 \%$ siklus I dan kembali meningkat menjadi $100 \%$ pada siklus II. Selanjutnya penelitian Widiartini (2017) dengan fokus meningkatkan aktivitas dan hasil belajar peserta didik menggunakan model inkuiri pada materi perubahan wujud kelas III SDN Jember LOR 1, hasil penelitian menunjukkan bahwa model 
inkuiri dapat meningkatkan aktivitas dan hasil belajar peserta didik

Berdasarkan latarbelakang sebagaimana yang diuraikan di atas jika kondisi tersebut dibiarkan mutu dan kualitas pendidikan khususnya di kelas VI SDN 18/IX Rengas Bandung dan mutu Pendidikan secara umum mendapatkan dampaknya.

Tujuan penelitian untuk mengetahui bagaimana penerapan model inkuiri dalam meningkatkan hasil belajar IPA materi hubungan antara ciri-ciri khusus yang dimiliki hewan dan tumbuhan pada peserta didik kelas VI SDN 18/IX Rengas Bandung.

\section{METODE PENELITIAN}

Metode yang digunakan dalam penelitian ini yaitu penelitian Tindakan kelas (classroom action research) sebagaimana Kemmis dan Mc Raggart (Jakni, 2017: 63) menyatakan "Action research study that was conducted to improve yourself, work experience itself is done in a systematic, planned, and the introspective attitude" bahwa penelitian Tindakan kelas merupakan studi yang dilakukan dalam rangka memperbaiki diri sendiri, pengalaman kerja yang dilakukan dengan sistematis, terencana dan sikap mawas. Selanjutnya Burns (Aqib, Z dan Amrullah, A, 2018: 37 -38) menyatakan bahwa aspek pokok dalam penelitian tindakan yaitu: Menyiapkan rencana tindakan, Bertindak, melakukan pengamatan secara individu dan Bersama sama, dan melakukan refleksi.

Mengingat dalam penelitian ini peneliti menerapkan model pembelajaran inquiri untuk meningkatkan hasil belajar peserta didik maka, jenis PTK yang digunakan yaitu PTK Eksperimental sebagaimana Paizaluddin dan Ermalinda, (2016: 29) menyatakan bahwa PTK dengan jenis eksperimental yaitu PTK yang dilakukan peneliti menggunakan strategi atau teknik tertentu dalam kegiatan belajar mengajar dalam rangka mencapai tujuan pembelajaran. Lokasi penelitian yaitu SD 18/IX Rengas Bandung. Subjek penelitian yaitu kelas VI dengan jumlah siswa sebanyak 26 yaitu 13 laki-laki dan 13 perempuan, waktu penelitian yaitu semester I (Ganjil) 
Tahun Ajaran 2019/2020 dilakukan tepatnya bulan Agustus s.d Oktober 2019, Teknik yang digunakan yaitu observasi terstruktur, dan tes hasil belajar peserta didik. Analisis yang digunakan dengan membandingkan nilai rata-rata skor hasil belajar peserta didik dengan kriteria keberhasilan yaitu KKM IPA sebesar 65 , rumus yang digunakan untuk menganalisis hasil observasi menggunakan rumus:

Presentase nilai rata-rata

$$
(\mathrm{NR})=\frac{\text { Jumlah } \text { Skor }}{\text { Jumlah Maksimal }} \times 100 \%
$$

Sedangkan rumus yang digunakan untuk menentukan ketuntasan belajar peserta didik secara klasikal yaitu:

$$
\mathrm{KK}=\frac{N}{s t} \times 100
$$

Keterangan:

KK : Ketuntasan klasikal

$\mathrm{N}$ : Jumlah peserta didik yang tuntas

ST : Jumlah peserta didik seluruhnya.

Hamdi, M (2018: 148)

Untuk memudahkan interpretasi data peneliti menggunakan kriteria penilaian dengn kategori rata-rata seperti pada tabel di bawah.
Tabel 1. Kriteria penilaian kategori rata-rata

\begin{tabular}{cc}
\hline Interval Nilai & Kategori \\
\hline $80,00-100,00$ & Sangat Baik \\
\hline $70,00-79,99$ & Baik \\
\hline $60,00-69,99$ & Cukup \\
\hline $50,00-59,99$ & Kurang \\
\hline$<50,00$ & Sangat Kurang \\
\hline
\end{tabular}

Berikutnya untuk memudahkan melakukan penerjemahan data hasil persentase menggunakan kategori seperti pada tabel berikut

Tabel 2. Tolok ukur Kategori Persentase

\begin{tabular}{cc}
\hline Persentase & Kategori \\
\hline $75,01-100,00$ & Sangat Baik \\
\hline $50,01-75,00$ & Baik \\
\hline $25,01-50,00$ & Cukup \\
\hline $00,00-25,00$ & Kurang \\
\hline
\end{tabular}

Adapun kriteria keberhasilan yang digunakan dalam penelitian ini yaitu:

a. Secara perorangan atau individu hasil belajar peserta didik telah mencapai KKM sebesar 65;

b. Ketuntasan klasikal sebesar $80 \%$.

\section{HASIL DAN PEMBAHASAN}

Sebelum peneliti memasuki tahap-tahap siklus I, kegiatan diawali dengan penjaringan ketuntasan hasil belajar peserta didik pra siklus yaitu diketahui bahwa dari 26 peserta didik kelas VI hanya empat peserta didik yang telah mencapai KKM 65 yaitu 
dua laki-laki dan dua perempuan sedangkan 22 peserta didik lainnya belum tuntas dengan rata-rata kelas sebesar 57,69 berada pada interval kategori Kurang, dengan kata lain persentase ketuntasan secara klasikal sebesar $15 \%$ kategori Kurang. Sekolah sendiri menetapkan KKM IPA Kelas VI sebesar 65 secara individu dan $80 \%$ tuntas secara klasikal.

\section{Siklus I}

\section{Perencanaan}

Tahapan perencanaan pada siklus I dimaksudkan untuk membuat dan atau menyiapkan segala sesuatu yang diperlukan sebelum akhirnya melaksanakan tahapan pelaksanaan kegiatan pembelajaran siklus I, kegiatan yang dilakukan peneliti pada tahap ini diantaranya: melakukan perizinan kepada kepala sekolah sekaligus memohon berkenannya untuk menjadi pengamat penelitian; menyiapkan materi pelajaran yang dimuat ke dalam RPP dengan penerapan model inkuiri berikut tes formatif, mempersiapkan lembar observasi aktivitas guru dan peserta didik, menentukan waktu pelaksanaan penelitian agar tidak bentrok dengan jadwal kegiatan di sekolah, melakukan konsolidasi bersama satu orang guru senior untuk kesediaannya menjadi pengamat/observer penelitian.

Adapun indikator aktivitas guru mempedomani langkah-langkah model inkuiri yang dikemukakan Chiaritto, (Sujana, A., \& Sopandi, P,W, 2017: 67) yang menyatakan 11 (sebelas) tahapan peran guru dalam pelaksanaan model inkuiri yang dikemas menjadi 10 (sepuluh) indikator aktivitas guru diantaranya:

Membuka pelajaran/ menyampaikan tujuan pembelajaran; (2) Memberikan situasi masalah (Encounter with the problem) terkait materi pelajaran; (3) Memosisikan diri sebagai mitra peserta didik; (4) Memberikan waktu dan kesempatan yang sama untuk mengekspresikan apa yang diketahui peserta didik; (5) Membimbing dan mendorong peserta didik menggunakan berbagai sumber dalam upaya membantu peserta didik mengajukan pertanyaan dan melakukan penyelidikan; (6) Merefleksikan pertanyaan yang disampaikan peserta didik; (7) Memfasilitasi peserta didik dalam 
mencapai pengetahuan;

Menciptakan lingkungan bebas

intelektual; (9) Memberikan

kesempatan yang sama kepada peserta didik untuk berinteraksi dengan baik dalam kelompok; (10)

Manajemen waktu.

Sedangkan indikator kegiatan peserta didik diantaranya: (1) Mengikuti pembelajaran dengan hikmat; (2) Ketertarikan dengan pelajaran; (3) Keaktifan bertanya; (4)

Keaktifan mengekspresikan pengetahuan yang dimiliki;

Menghubungkan pengetahuan yang dimiliki dengan pengetahuan baru; (6) Mendiskusikan pengetahuan dalam kelompok; (7) Berkomunikasi dan bekerjasama dengan baik sesama anggota kelompok; (8) Mengenal karakteristik teman dalam kelompok; (9) Merefleksikan argumentasi dengan berfikir kritis dan kreatif; (10) Memecahkan masalah dengan melakukan penyelidikan.

\section{Tindakan}

Tahapan Tindakan siklus I merupakan langkah lanjutan dari tahap rencana Tindakan, pada prosesnnya peneliti melakukan kegiatan nyata proses pembelajaran materi hubungan antara ciri-ciri khusus yang dimiliki hewan dan tumbuhan dengan penerapan model inkuiri, pembelajaran dilakukan dengan mempedomani skenario pembelajaran yang telah disusun sebelumnya di

RPP.

Tabel 1. Sebaran Ketuntasan Belajar Siklus I

\begin{tabular}{|c|c|c|c|c|c|c|c|}
\hline \multirow{2}{*}{ Siklus } & \multicolumn{2}{|c|}{ Tuntas } & \multirow{2}{*}{$\begin{array}{c}\mathrm{Jml} \\
(80 \%)\end{array}$} & \multicolumn{2}{|c|}{ Tidak } & \multirow{2}{*}{$\begin{array}{c}\text { Jml } \\
(20 \%)\end{array}$} & \multirow{2}{*}{$\begin{array}{c}\text { Rata-rata } \\
\text { (Kategori) }\end{array}$} \\
\hline & $\mathrm{L}$ & $\mathrm{P}$ & & $\mathrm{L}$ & $\mathrm{P}$ & & \\
\hline Pra & 2 & 2 & $15 \%$ & 11 & 11 & $85 \%$ & $\begin{array}{c}57,69 \\
\text { (Kurang) }\end{array}$ \\
\hline I & 7 & 9 & $62 \%$ & 6 & 4 & $38 \%$ & $\begin{array}{c}64,15 \\
\text { (Cukup) }\end{array}$ \\
\hline
\end{tabular}

Jika dilihat ketuntasan hasil belajar siklus I, persentase ketuntasan belajar peserta didik secara umum mengalami peningkatan yaitu ketuntasan pra siklus sebesar 15\% meningkat menjadi $62 \%$ terdiri dari tujuh peserta didik laki-laki dan
Sembilan peserta didik perempuan, rata-rata skor pra siklus 57,69 kategori "Kurang" meningkat menjadi 64,15 kategori “Cukup".

\section{Observasi}

Kegiatan pada tahap observasi berlangsung bersamaan dengan 
pelaksanaan tindakan dalam hal ini kolaborator penelitian yaitu satu orang kepala sekolah dan satu orang guru senior SDN 18/IX Rengas Bandung berperan sebagai observer memasuki kelas dengan menempatkan posisi yang tidak menganggu kenyamanan peserta didik, tidak mengintervensi pembelajaran, dan menghindari munculnya kegelisahan peserta didik atas kehadiran kolaborator, bertindak sebagai pengamat melakukan penilaian atas data yang direkam dari pelaksanaan pembelajaran di lembar observasi yang telah peneliti persiapkan sebelumnya. Adapun hasil observasi siklus I yaitu: total skor yang diperoleh pada lembar observasi aktivitas guru yaitu sebesar 26 dengan persentase skor sebesar $65 \%$ kategori "Baik", sedangkan total skor yang diperoleh pada lembar kegiatan peserta didik yaitu sebesar 24 dengan persentase skor sebesar $60 \%$ yang berada pada kategori "Baik"

\section{Refleksi}

Tahapan refleksi dilakukan bersama kolaborator penelitian untuk mengkaji hasil pelaksanaan siklus I sekaligus membuat keputusan hasil pelaksanaan siklus I. ketuntasan hasil belajar peserta didik setelah pelaksanaan siklus I mengalami peningkatan dengan signifikan, namun kendatipun hasil pelaksanaan siklus I menambah jumlah ketuntasan belajar peserta didik masih terdapat 10 peserta didik yang belum mencapai KKM 65 yaitu enam lakilaki dan empat perempuan, atau ketuntasan klasikal baru diperoleh sebesar $65 \%$ sedangkan kriteria keberhasilan penelitian mengikuti kriteria ketuntasan yang ditetapkan sekolah yaitu $80 \%$ tuntas secara klasikal dengan demikian penelitian berlanjut pada siklus II dengan menjalani tahapan yang sama seperti siklus I yaitu perencanaan, Tindakan, observasi dan refleksi. Adapun beberapa hal yang perlu direvisi untuk dilaksanakan Kembali pada siklus II diantaranya: Mengintensifkan pemberian waktu dan kesempatan yang sama kepada peserta didik untuk mengekspresikan apa yang diketahui; (2) Membimbing dan mendorong peserta didik menggunakan berbagai sumber dalam upaya membantu peserta didik mengajukan pertanyaan dan 
melakukan penyelidikan perlu ditingkatkan dengan menampilkan berbagai varian cara dan sumber serta lebih memperhatikan karakteristik setiap peserta didik;

Merefleksikan pertanyaan yang disampaikan peserta didik lebih dimaksimalkan dengan cara menjelaskan dengan lebih gamblang mengangkat contoh yang berhubungan langsung dengan aktivitas sehari hari agar lebih mudah dicerna; (4) Menciptakan lingkungan bebas intelektual perlu ditingkatkan, sesuai dengan karakteristik model inkuiri yang memberikan peluang kepada peserta didik untuk melakukan eksplorasi dan menemukan sendiri; (5) Memberikan kesempatan yang sama kepada peserta didik untuk berinteraksi dengan baik dalam kelompok dengan cara menyakinkan setiap peserta didik semua berada pada posisi yang sama termasuk guru yaitu bagaimana menyelesaikan masalah yang ada; (6) Manajemen waktu perlu diperhatikan. Setelah memasuki tahapan refleksi siklus I, akhirnya peneliti dapat melihat dengan lebih jelas pengalaman belajar apa yang perlu ditingkatkan, dan bagaimana cara melaksanakannya.

\section{Sikluis II}

Pelaksanaan siklus II merupakan lanjutan dari hasil pada tahap refleksi siklus I, seperti tahapan siklus I, tahapan yang dilakukan pada siklus II juga menempuh tahapan yang sama yaitu membuat perencanaan dengan mempedomani hasil yang direvisi pada pelaksanaan siklus I, pelaksanaan tindakan, observasi dan refleksi. Setelah melakukan tahapan pelaksanaan tindakan, hasil pelaksanaan siklus II dapat dilihat pada tabel berikut:

Tabel 2. Sebaran Ketuntasan Belajar Siklus II

\begin{tabular}{|c|c|c|c|c|c|c|c|}
\hline \multirow{2}{*}{ Siklus } & \multicolumn{2}{|c|}{ Tuntas } & \multirow{2}{*}{$\begin{array}{c}\text { Jml } \\
(80 \%)\end{array}$} & \multicolumn{2}{|c|}{ Tidak } & \multirow{2}{*}{$\begin{array}{c}\text { Jml } \\
(20 \%)\end{array}$} & \multirow{2}{*}{$\begin{array}{c}\text { Rata-rata } \\
\text { (Kategori) }\end{array}$} \\
\hline & $\mathrm{L}$ & $\mathrm{P}$ & & $\mathrm{L}$ & $\mathrm{P}$ & & \\
\hline Pra & 2 & 2 & $15 \%$ & 11 & 11 & $85 \%$ & 57, 69 (Kurang) \\
\hline I & 7 & 9 & $62 \%$ & 6 & 4 & $38 \%$ & 64, 15 (Cukup) \\
\hline II & 12 & 12 & $92 \%$ & 1 & 1 & $8 \%$ & 71,58 (Baik) \\
\hline
\end{tabular}


Berdasarkan hasil pelaksanaan siklus II, secara signifikan hasil belajar peserta didik menunjukan peningkatan, kendatipun ketuntasan klasikal yang diperoleh hanya 92\% atau masih terdapat delapan persen atau dua peserta didik lainnya yang belum tuntas namun ketuntasan belajar peserta didik sudah mencapai kriteria keberhasilan penelitian.

Hasil observasi aktivitas guru siklus II juga mengalami peningkatan yaitu total skor yang sebelumnya 26 pada siklus I meningkat menjadi 32 pada siklus II dengan persentase sebelumnya $65 \%$ kategori "baik" pada siklus I meningkat menjadi $80 \%$ kategori "sangat baik" pada siklus II, hasil yang cenderung sama juga terjadi pada hasil observasi kegiatan peserta didik yaitu: total skor yang sebelumnya 24 pada siklus I meningkat menjadi 31 pada siklus II dengan persentase sebelumnya $60 \%$ kategori "Baik" pada siklus I meningkat menjadi $78 \%$ kategori "Sangat Baik" pada siklus II. Mengingat kriteria keberhasilan penelitian telah tercapai pada pelaksanaan siklus II maka penelitian berakhir pada siklus II.
Terkait hasil belajar dalam pelajaran IPA sebagaimana yang diperoleh peserta didik dalam penelitian ini sejalan dengan penelitian yang dilakukan Widiyawati, I (2018) penelitian berjenis Pre-Experimental Design (nondesaigns) dengan fokus meningkatkan hasil belajar IPA dengan subjek kelas 3 beranggotakan 30 peserta didik SDN 06 Larangan menyatakan dalam studi pendahuluannya bahwa guru dalam pengaplikasian pelajaran IPA di SD seyogianya menggunakan berbagai media yang bertujuan agar peserta didik dapat dengan mudah memahami materi dan tidak bosan mengikuti proses pembelajaran. Lebih lanjut penelitian Eksperimen dengan fokus meningkatkan hasil belajar mata pelajaran IPA oleh Oktaviani, M, H (2018:115) menyatakan bahwa kesesuaian gaya belajar peserta didik, model pembelajaran dan metode pembelajaran merupakan hal-hal yang memengaruhi peserta didik dalam memahami materi IPA dengan baik. 


\section{SIMPULAN}

Berdasarkan hasil dan temuan penelitian yang dipaparkan pada hasil dan pembahasan dapat disimpulkan bahwa penerapan model inkuiri dapat meningkatkan hasil belajar IPA materi hubungan antara ciri-ciri khusus yang dimiliki hewan dan tumbuhan pada peserta didik kelas VI SDN 18/IX Rengas Bandung, hal tersebut sebagaimana terlihat pada hasil pelaksanaan siklus I dan siklus II.

Selanjutnya berdasarkan simpulan penelitian beberapa saran yang peneliti berikan yaitu: (1) hasil penelitian ini dapat dijadikan masukan untuk meningkatkan kualitas dan hasil belajar peserta didik dalam menjalani pembelajaran di sekolah; (2) hasil penelitian ini dapat dijadikan alternatif solusi manakala berhadapan dengan kesenjangan sejenis yang peneliti lakukan dengan memerhatikan karakteristik model inkuiri, karakteristik mata pelajaran dan situasi kelas, bagi peneliti; (3) hasil penelitian dapat menjadi referensi dalam melakukan penelitian khususnya penelitian perbandingan dengan melakukan pengujian secara ilmiah dalam bidang penelitian Pendidikan dan pengajaran

\section{DAFTAR PUSTAKA}

Aqib, Z., \& Amrullah, A. 2018. Penelitian Tindakan Kelas Teori \& Aplikasi. Yogyakarta: ANDI OFFSET.

Badan Standar Nasional Pendidikan. 2006. Standar Isi untuk Satuan Pendidikan Dasar dan Menengah; Standar Kompetensi dan Kompetensi Dasar SD/MI. Jakarta: Badan Standar Nasional Pendidikan (BSNP).

Hamdi, M. 2018. Penelitian Tindakan Sekolah (PTS) Teori dan Praktis dalam Pendidikan. Jambi: UNJA Press.

Jakni. 2017. Penelitian Tindakan Kelas. Bandung: Al-Fabeta.

Jamalia. 2017. Meningkatkan Hasil Belajar Bahasa Indonesia Menggunakan Model Inkuiri pada Siswa Kelas V SDN 104/IX Kedemangan. Media Penelitian Pendidikan, Volume 11(No 2), Desember, hal.97 - 104.

Oktaviani, M. H. 2018. Pengaruh Model Pembelajaran Course Review Horay Terhadap Hasil Belajar Mata Pelajaran IPA Materi Ciri-ciri Mahluk Hidup Siswa Kelas III SDN 02 Ngawen PATI. Jurnal 
Volume 3 Nomor 1, Edisi Juni 2020

Prodi PGSD Universitas Slamet Riyadi

ISSN 2620-6560 (print) ISSN 2620-746X (online)

SINEKTIK, Volume 1(No. 1), Juni, hal. p-112 - 119.

Paizaluddin, \& Ermalinda. 2016. Penelitian Tindakan Kelas (Clasroom Action Research) Panduan Teoritis dan Praktis (3 ed.). Bandung: Al-Fabeta.

Sanjaya, W. 2010. Kurikulum dan Pembelajaran Teori dan Praktik Pengembangan Kurikulum Tingkat Satuan Pendidikan. Jakarta: Kencana Prenada Media Group.

Sujana, A., \& Sopandi, P. W. 2017. Model-model Pembelajaran Inovatif Teori dan Implementasi. Jakarta: PT. RajaGrafindo Persada.

Trianto. 2007. Model-model Pembelajaran Inovatif Berorientasi Konstruktivistik. Jakarta: Media Group.

Widiartini, E. L. 2017. Penerapan Model Pembelajaran Inkuiri untuk Meningkatkan Aktivitas dan Hasil Belajar pada Materi Perubahan Wujud Siswa Kelas 3 di SDN Jember LOR 1. Jurnal Pembelajaran Fisika, Volume 5(No. 4), Maret., hal.337 - 342.

Widiyawati, I. 2018. Keefektifan Macromedia Flash Terhadap Hasil Belajar IPA Siswa Kelas III SDN Negeri 06 Larangan. Jurnal SINEKTIK, Volume 1(No. 1), Juni, hal.p-40 - 45. 